\title{
Voice vs. Silence
}

By N.N.

- Desideratum

Evernote keywords: issues tagged for first-priority treatment in this entry

- activism, activist(s) (QTh)

- Avaaz

- public opinion $=$ Chaos

- 'Azza Ḥinnāwī (Henawy)

- public sphere

- book covers

- calm vs. noise

- publishers, publishing houses

- courage $v s$. fear/timidity

- raise criticism, speak up to power, speaking up

- critics

- cultural cleansing

- cultural spaces

- cultural struggle

- emotion(s), emotional

- right to speak

- scandal(s)

- secret

- social criticism

- social mobilisation

mobilisation, emotionalism

- special issue for Aḥmad Nāgī

- summary of all scandals

- Ğum'at al-Ghadab, the Day of

- Ṭantā University Faculty of Medicine (9/4/2016) Rage $(Q T h)$

- my voice

- theatre

- Omar Hayek

- political activism

- political advertising

- polls, ing

- press

- protest(s), protest marches

- voice $(Q T h)$, to have a voice, listen to me!

- vote

- wall slogans

- whistle-blowing

- who can speak/decide in the name of the Brotherhood?

- public arguing, public criticism/critique

- public discourse

- women in parliament

- words

- writers

- al-Zāwiya

Entries pointing here

ARRAYS - Commemoration / Memorial Days $\downarrow$ Court Trials $\downarrow$ Father Figures $\downarrow$ LGBT $\downarrow$ Manīsh $m s \overline{a m i h} \star$ The Policeman Criminal $\downarrow$ Red Sea Islands $\star$ Social Media $\downarrow$ The Suspect Foreigner $\downarrow$ The Voice from Above

CODES - Past vs. Present 